\title{
Compensatory growth after feed restriction during the rearing period in pigs
}

\author{
Jarmo Valaja, Timo Alaviuhkola, Kaija Suomi and Irma Immonen \\ Valaja, J., AlaviuhKola, T., SuOMi, K. \& Immonen, I. 1992. Compensatory growth \\ after feed restriction during the rearing period in pigs. Agric. Sci. Finl. 1: 15-20. \\ (Agric. Res. Centre of Finland, Swine Res. Sta., SF-05840 Hyvinkää, Finland).
}

The compensatory growth after feed restriction was studied in an experiment with 120 pigs which were divided into two test treatments: control $(\mathrm{C})$ and restricted $(\mathrm{R})$ feeding. During the first period, from the age of seven weeks to $25 \mathrm{~kg}$ of live weight, $\mathrm{R}$ pigs were fed twice and $\mathrm{C}$ pigs three times the maintenance level. During the second period, from $25 \mathrm{~kg}$ to $100 \mathrm{~kg}$ of live weight, both treatments were given the same amount of feed from 1.4 to 3.2 feed units/pig/day.

The daily feed intake of $\mathrm{R}$ pigs was significantly lower $(\mathrm{p}<0.001)$ than that of $\mathrm{C}$ pigs during the restriction period $(0.69 \mathrm{vs} .0 .99 \mathrm{FU} / \mathrm{pig} / \mathrm{d})$. R pigs gained also significantly less weight $(\mathrm{p}<0.01)$ than $\mathrm{C}$ pigs $(344 \mathrm{vs} .527 \mathrm{~g} / \mathrm{d})$ and the length of the first period was longer for $\mathrm{R}$ pigs compared to $\mathrm{C}$ pigs $(\mathrm{p}<0.001)$.

During the second period $\mathrm{R}$ pigs compensated the retarded growth caused by feed restriction. $\mathrm{R}$ pigs gained significantly more weight $(\mathrm{p}<0.01)$ than $\mathrm{C}$ pig $(955 \mathrm{vs} .924$ $\mathrm{g} / \mathrm{d})$ and feed conversion efficiency (FCE) was better ( 2.52 vs. $2.60 \mathrm{FU} / \mathrm{kg}$ gain) $(p<0.05)$. Significant differences were found also between the treatments in the length of the second period $(\mathrm{p}<0.05)$ and in the total feed consumption $(\mathrm{p}<0.05)$. No differences were found in carcass composition between the treatments.

Fullsib test indexes were calculated from the results of the second period for both treatments based on the method used in Finnish on-station progeny testings. The index means for $\mathrm{C}$ and $\mathrm{R}$ pigs were 2.7 and 6.3 , respectively.

Key words: pig, feed restriction, compensatory growth.

\section{Introduction}

It is known that many animal species exhibit a capacity to compensate for the retarded growth after periods of underfeeding (ROBINSON 1964). Especially in ruminants the compensatory growth effect is well established. Many reports have shown also that the weight gain of growing pigs increases during ad libitum feeding following a period of restricted feeding (OWEN et al. 1971, KIRCHGESSNER et al. 1979, GÄDEKEN et al. 1983), but some studies have not found any compensatory effect (Pond and Mersmann 1990).

Performance testing programs are based on the assumption that environment and nutrition before the test period have little or no influence on performance during the test period. However, the results of the progeny test in Finland show that the older pigs often get better performance results in the test than younger ones (PUONTI 1991). Whether the difference in the age is related to the feed restriction during the pretest period is not known for sure.

The present study was undertaken to examine the possible compensatory growth effect after feed 
restriction in the rearing period and to find out whether pretest feed restriction affects the results of fullsib tests.

\section{Material and methods}

Compensatory growth was studied in an experiment with 120 Landrace and Yorkshire female and castrated pigs. Pigs from fifteen litters were divided into 30 groups of four litter mates ( 2 females and 2 castrates). From each litter, one group was assigned to control (C) and one group to restricted (R) feeding.

The experiment was divided into two periods. During the first period, from seven weeks of age to $25 \mathrm{~kg}$ of live weight, the control group (C) was fed three times and the restricted group (R) twice the maintenance level $\left(0.46 \mathrm{MJ} \mathrm{ME} / \mathrm{kg} \mathrm{W}^{0.75}\right)$ on group feeding (ARC 1981). The daily feed allowance was changed according to weight twice a week.

The second experiment period started when the mean weight of the pen ( 4 animals) reached $25 \mathrm{~kg}$. There was no adjustment period between the test periods. From $25 \mathrm{~kg}$ to $100 \mathrm{~kg}$ of live weight both treatments were on group feeding restricted according to weight from 1.4 to $3.2 \mathrm{FU} / \mathrm{pig} / \mathrm{day}$. The same commercial pelleted diet was fed to both treatments (Table 1).

Animals were housed in concrete floor pens, four

Table 1. Dietary ingredients (\%) and chemical composition $(\%)$ of the experimental diet.

Ingredients:

Barley

Soya bean meal

Milk powder

Fish meal

Mineral + vitamin mix

Chemical composition (calculated):

Digestible crude protein, \%

Feed unit $(\mathrm{FU} / \mathrm{kg})^{1}$

$\mathrm{ME}, \mathrm{MJ} / \mathrm{kg}$

1. $\mathrm{FU}=0.7 \mathrm{~kg}$ starch equivalent. in each, and fed twice a day. Weight gain and feed consumption were recorded weekly during the experiment. At slaughter, the carcass was evaluated according to the procedure used for the fullsib test pigs (Kantakoe-eläinten... 1979).

The fullsib test index (K-index) was calculated by the Finnish Animal Breeding Association for each pen of four animals from the results of the second period (PuONTI 1988). The test index formula used for the calculations was:

$\mathrm{K}$-index $=\mathrm{a}_{1}(\mathrm{~T}-\overline{\mathrm{T}})+\mathrm{b}_{1}(\mathrm{U}-\overline{\mathrm{U}})+\mathrm{c}_{1}(\mathrm{~L}-\overline{\mathrm{L}})+\mathrm{d}_{1}(\mathrm{~N}-\overline{\mathrm{N}})+\mathrm{e}_{1}$ $(\mathrm{O}-\overline{\mathrm{O}})+4.0$.

$\mathrm{T}, \mathrm{U}, \mathrm{L}, \mathrm{N}$ and $\mathrm{O}$ are the results of the test group as follows:

$\mathrm{T}=$ daily gain, $\mathrm{g} / \mathrm{d}$

$\mathrm{U}=$ feed conversion, $\mathrm{FU} / \mathrm{kg}$ gain

$\mathrm{L}=$ fat in back and loin, $\%$

$\mathrm{N}=$ lean meat in carcass, $\%$

$\mathrm{O}=$ meat quality score

$\overline{\mathrm{T}}, \overline{\mathrm{U}}, \overline{\mathrm{L}}, \overline{\mathrm{N}}$ and $\overline{\mathrm{O}}$ are reference values. $\overline{\mathrm{T}}$ and $\overline{\mathrm{U}}$ are two month averages of the test station. $\overline{\mathrm{L}}$ and $\overline{\mathrm{N}}$ are two month averages of the breed. $\mathrm{O}$ is the average meat quality of the carcasses of the test pigs slaughtered on the same day in the same slaughterhouse. $a_{1}, b_{1}, c_{1}, d_{1}$ and $e_{1}$ are statistical weighting factors according to the size of the test group.

The data was subjected to analysis of variance using the GLM procedure of SAS (1985). The results of each individual animal were used as observations for the statistical analyses except for the feed consumtion and for the feed conversion efficiency, the mean of the pen (4 animals) was used. The model used to analyse the data was $\mathrm{Y}_{\mathrm{ijk}}=\mu+\mathrm{T}_{\mathrm{i}}+\mathrm{L}_{\mathrm{j}}+\mathrm{e}_{\mathrm{ijk}}$, where

$\mathrm{Y}_{\mathrm{ijk}}=$ each individual observation

$\mu=$ overall mean

$\mathrm{T}_{\mathrm{i}}=$ effect of the treatment $(\mathrm{i}=1,2)$

$\mathrm{L}_{\mathrm{j}}=$ effect of the litter $(\mathrm{j}=1, \ldots, 15)$

$\mathrm{e}_{\mathrm{ij \textrm {k }}}=$ residual term.

\section{Results}

\section{Period 1}

In the beginning of the first period, at the age of seven weeks, the weight of the control (C) and 
restricted (R) pigs was 16.9 (s.e. 0.37 ) and 17.2 (s.e. 0.29) kg, respectively (Table 2). The feed regimes of the treatment groups were designed to be twice or three times the maintenance level, and the object was reached fairly well, because the feed consumption (FU/pig/day) of R pigs was $70 \%$ of that of $\mathrm{C}$ pigs (Table 2).

Because of the different feed regimes for $\mathrm{R}$ and $\mathrm{C}$ pigs, the daily gain and the length of the first period were significantly different between the groups $(\mathrm{p}<0.001)$ (Table 2). The total feed consumption over the period and the feed conversion efficiency (FCE) did not differ significantly between the treatments (Table 2). However, there was a tendency for better FCE for $\mathrm{C}$ pigs $(\mathrm{p}=0.06)$.

\section{Period 2}

In the beginning of the second period the mean weight of the two treatment groups was $25.2 \mathrm{~kg}$. During the period C pigs gained $3.4 \%$ less (924 vs. $955 \mathrm{~g} / \mathrm{d})$ than R pigs $(\mathrm{p}<0.01)$ (Table 2). R pigs also reached the final weight 2.8 days earlier than $\mathrm{C}$ pigs, and the difference was statistically significant $(\mathrm{p}<0.05)$.

Refusals of the diet were negligible although there was no adjustment time between the test periods. The daily feed consumption was not different between the treatments. However, $\mathrm{C}$ pigs consumed more feed than $\mathrm{R}$ pigs over the whole period $(\mathrm{p}<0.05)$ (Table 2). Because of the faster growth and lower feed consumption of $\mathrm{R}$ pigs their feed conversion efficiency was also significantly

Table 2. Performance and carcass quality of pigs on control and restricted feeding.

\begin{tabular}{|c|c|c|c|c|}
\hline Feeding & Control & Restricted & SEM $^{1}$ & Level of signif. \\
\hline \multicolumn{5}{|l|}{ Period 1} \\
\hline No of animals & 60 & 60 & & \\
\hline Initial weight, kg & 16.9 & 17.2 & 0.24 & NS \\
\hline Final weight, kg & 25.2 & 25.2 & 0.28 & NS \\
\hline Days in exp. period & 16.3 & 23.3 & 0.41 & NS \\
\hline Daily gain, g & 527 & 344 & 9.15 & $* * *$ \\
\hline \multicolumn{5}{|l|}{ Feed consumption, } \\
\hline $\mathrm{kg} / \mathrm{pig}$ & 15.8 & 16.1 & 0.75 & $* * *$ \\
\hline FU/pig/day ${ }^{2}$ & 0.99 & 0.69 & 0.02 & $* * *$ \\
\hline $\mathrm{FCE}, \mathrm{FU} / \mathrm{kg}$ gain & 1.88 & 2.01 & 0.04 & NS \\
\hline \multicolumn{5}{|l|}{ Period 2} \\
\hline Initial weight, kg & 25.2 & 25.2 & 0.24 & NS \\
\hline Final weight (corr)kg & 100.1 & 99.9 & 0.30 & NS \\
\hline Slaughter weight, kg & 74.1 & 73.9 & 0.27 & NS \\
\hline Loss at slaughter, $\%$ & 25.9 & 26.1 & 0.13 & NS \\
\hline Days in exp. period & 81.5 & 78.7 & 0.85 & $*$ \\
\hline Daily gain, $\mathrm{g}$ & 924 & 955 & 7.79 & $* *$ \\
\hline \multicolumn{5}{|l|}{ Feed consumption, } \\
\hline $\mathrm{kg} / \mathrm{pig}$ & 196.0 & 189.8 & 1.83 & $*$ \\
\hline FU/pig/day & 2.39 & 2.40 & 0.01 & NS \\
\hline $\mathrm{FCE}, \mathrm{FU} / \mathrm{kg}$ gain & 2.60 & 2.52 & 0.02 & $*$ \\
\hline Side fat, $\mathrm{mm}$ & 15.9 & 16.1 & 0.41 & NS \\
\hline Eye muscle area, $\mathrm{cm}^{2}$ & 42.3 & 41.9 & 0.43 & NS \\
\hline Colour of lean (scaleEEL) ${ }^{3}$ & 35.3 & 36.3 & 0.57 & NS \\
\hline Meat in valuable cuts, $\%$ & 80.4 & 80.4 & 0.28 & NS \\
\hline Meat in carcass, $\%$ & 53.8 & 53.7 & 0.22 & NS \\
\hline
\end{tabular}

1. $\mathrm{SEM}=$ Standard error of means; significance:NS (non-significant), ${ }^{*}(\mathrm{p}<0.05),{ }^{* *}(\mathrm{p}<0.01),{ }^{* * *}(\mathrm{p}<0.001)$.

2. $\mathrm{FU}=$ feed unit

3. $\mathrm{EEL}=$ smoke stain reflectometer. 
better than that of $C$ pigs $(2.52$ vs. 2.60$)(p<0.05)$. In slaughter results there were no differences between the treatment groups (Table 2).

The fullsib test index means for $\mathrm{C}$ and $\mathrm{R}$ treatments were 2.7 (s.e. 2.20 ) and 6.3 (s.e. 1.81), respectively. The production result shares of the index (feed conversion and daily gain) were -2.1 (s.e. 1.31) and 1.9 (s.e. 1.36), carcass quality (lean meat in carcass and fat in back and loin) 0.2 (s.e. 1.19 ) and -0.2 (s.e. 0.58 ) and meat quality 0.6 (s.e. 0.39 ) and 0.6 (s.e. 0.35 ) for $\mathrm{C}$ and $\mathrm{R}$ pigs, respectively.

\section{Discussion}

In the present study, the compensatory growth was studied after feed restriction during the postweaning period (17-25 kg live-weight) before the beginning of the fullsib test period, because it was assumed to be close to the practice in Finland. In previous reports the period of feed restriction occurred during weaning (GÄDEKEN et al. 1983, KaUfmanN et al. 1989), growing (Prince et al. 1983, CAMPBell et al. 1983, DonKer et al. 1986) or early finishing (MersmanN et al. 1987). The compensatory growth has been studied both after restriction in nutrient density of the diet (PoND and Mersman 1990, PatTerson 1985) and after restriction in feed allowance (PRINCE et al. 1983, KAUFMANN et al. 1989).

The severity of the feed restriction was $30 \%$ in the present experiment compared to previous studies where the restriction has varied from $15 \%$ (PRINCE et al. 1983, DONKER et al. 1983) to $45 \%$ (GÄDEKEN et al. 1983, CAMPBELL et al. 1983). In contrast to the studies, Mersmann et al. (1987) and POND and MERSMANN 1990) induced feed restriction which led to actual weight loss of the animals.

In addition to retarded weight gain there was also a tendency to reduced feed conversion efficiency during the restriction in our study, but the difference was insignificant $(\mathrm{p}=0.06)$. This is in agreement with the studies of GÄDEKEN et al. (1983) and KAUFMANN et al. (1989) where feed restriction during weaning has caused retarded weight gain and reduced feed conversion efficiency compared to ad libitum feeding. However, the feed restriction during the growing period has had no effect on the feed conversion efficiency (PrINCE et al. 1983, CAMPBELL et al. 1983, DONKER et al. 1986).

After feed restriction, the compensatory growth effect increased the daily gain and improved the feed conversion efficiency in our study. The previous studies also confirm this effect (GÄDEKEN et al. 1983, Prince et al. 1983, CAMPBell et al. 1983, DonKer et al. 1986, Mersmann et al. 1987, Kaufmann et al. 1989). In contrast to the above studies POND and MERSMANn (1990) could not find any compensatory effect probably because of the severity of the feed restriction which led to a $20 \%$ weight loss during the restriction period. Because of the absence of an adjustment period between the test periods in our study there may have been a slight possible difference in the gut fill between the treatments in the beginning of the second period. According to JUST (1984), it was estimated to be insignificant.

The compensatory responses are influenced by the severity of restriction and by the length of the restriction period (RoBINSON 1964, PRINCE et al. 1983, DonKer et al. 1986, CAMpBell et al. 1983). The optimum level of restriction for growing pigs to induce compensatory growth seems to be $72-85 \%$ of ad libitum feed intake according to DONKER et al. (1986).

Increased weight gain of the $\mathrm{R}$ pigs in the second period could not totally compensate for the slower growth rate during the first period in our experiment. The average daily gain during the whole experiment was 851 and $811 \mathrm{~g} / \mathrm{d}$ for $\mathrm{C}$ and $\mathrm{R}$ pigs, respectively. In the studies of Prince et al. (1983), CAMPBELL et al. (1983) and DONKER et al. (1986), the compensatory effect completely compensated for retarded weight gain during the growing period $(20-60 \mathrm{~kg}$ live weight) compared to ad libitum fed pigs, and the overall growth rate was equal for both groups. The restricted feed pigs also used feed more efficiently than ad libitum fed pigs during the whole experiment in the above reports, which is in agreement with this study ( 2.49 vs. $2.55 \mathrm{FU} / \mathrm{kg}$ gain).

No difference was found in the carcass 
composition between the treatments. This confirms the results of Prince et al. (1983) and KAUfMANN et al. (1989). In some reports, compensatory growth has produced leaner carcasses compared to ad libitum feeding (GÄDEKEN et al. 1983, CAMPBELL et al. 1983, DONKER et al. 1986).

Compensatory growth can be exhibited by two ways:increased gain due to increased feed intake and/or improved feed conversion efficiency (DONKER et al. 1986). In the present study, the daily feed intake was restricted by weight during the second period. Therefore the $\mathrm{R}$ pigs compensated by improving their feed conversion efficiency. Ac- cording to GÄDEKEN et al. (1983) and FANDREJEWSKI (1986), compensatory growth is caused by a higher protein digestibility and a higher efficiency of utilization. The increased protein deposition was also connected with the slightly decreased fat deposition (GÄDEKEN et al. 1983).

According to our study it is possible that pretest feed restriction affects the results of progeny test. The similar environment and feeding during the pretest period is one way of avoiding errors. The other possible way to prevent the misuse of compensatory growth is to prescribe the maximum age of pigs in the beginning of the test period.

\section{References}

Agricultural Research Council. 1981. The nutrient requirements of pigs. Commonwealth Agricultural Bureaux, Slough. 304 p.

CAMPBell, R.G., TAVERner, M.R. \& Curic, D.M. 1983. Effect of feeding level from 20 to $45 \mathrm{~kg}$ on the performance and carcass composition of pigs grown to $90 \mathrm{~kg}$ live weight. Livest. Prod. Sci. 10: 265-272.

DONKer, R.A., HaRTOG, L.A. DEN, Brascamp, E.W., Merks, J.W.E., NoOrdewier, G.J. \& Buiting, G.A.J. 1986. Restriction of feed intake to optimize the overall performance and composition of pig. Livest. Prod. Sci. 15: 353-365.

FANDREJEWSKI, H. 1986. Effect of two feeding levels in the early stage of growth and protein retention in pigs. Proc. 37th Annual Meeting of EAAP, Budapest. p. 283.

GÃdeken, D., Böhme, H. \& Oslage, H.J. 1983. Protein und Energieumsatz bei Wachsenden Sweinen unter Einfluss des kompensatorischen Wachstums. Arch. Tierernährung 33: 125-140.

JUST, A. 1984. Nutritional manipulation and interpretation of body compositional differences in growing swine. J. Anim. Sci. 58: 740-752.

Kantakoe-eläinten teurasarvostelu ja paloittelu. 1979. Sika 9: 34-35.

KaufmanN, A., Gerwig, C. \& KunZi, N. 1989. Einfluss von Aufzuchtintensität auf die Testmast beim Schwein. Schweine-Zucht und Schweine-mast 37: 240-241.

Kirchgessner, M., Dammert, S. \& Giessler, H. 1979. Kompensatorisches Wachstum bei stark reduzierter Ernăhrungsintensităt von Ferkeln während der Aufzucht bis 30 kg Lebendmasse. Züchtungskunde 51: 96-102.

Mersmann, H.J., Macneil, M.D., Seideman, S.C. \& Pond, W.G. 1987. Compensatory growth in finishing pigs afer feed restriction. J. Anim. Sci. 64: 752-764.

OWEN, J.B., RidGman, W.J. \& WYLliE, D. 1971. The effect of food restriction on subsequent voluntary intake of pigs. Anim. Prod. 13: 537-546.
Patterson, D.C. 1985. The effect of nutrient density of the diet and of a change in nutrient density on the performance of pigs fed ad libitum for bacon. Anim. Prod. 40: 169-174.

Pond, W.G. \& Mersmann, H.J. 1990. Differential compensatory growth in swine following control of intake by a high-alfalfa diet fed ad libitum or by limited feed. J. Anim. Sci. 68: 352-362.

Prince, T.J., Jungst, S.B. \& KuHlers D.L. 1983. Compensatory responses to short-term feed restriction during the growing period in swine. J. Anim. Sci. 56: 846-852.

PuONTI, M. 1988. Sikakantakokeet. Sianjalostajien yhdistyksen vuosikirja p. 27-29.

PuONTI, M. 1991. Personal communication. Finnish Animal Breeding Association. Vantaa, Finland.

RoBINSON, D.W. 1964. The plane of nutrition and compensatory growth in pigs. Anim. Prod. 6: 227-236.

SAS. 1985. SAS User's Guide: Statistics. 5th Ed. SAS Institute Inc, Cary, NC, USA. 956 p.

Manuscript received August 1991

Jarmo Valaja

Timo Alaviuhkola

Kaija Suomi

Agricultural Research Centre of Finland

Swine Research Station

SF-05840 Hyvinkää, Finland

Irma Immonen

Agricultural Research Centre of Finland

Swine Research Station

SF-05840 Hyvinkää, Finland

Present adress:

Kruununkatu 64

SF-05840 Hyvinkää, Finland 


\title{
SELOSTUS
}

\section{Lihasikojen kompensatorinen kasvu porsaskauden rajoitetun ruokinnan jälkeen}

\author{
Jarmo Valaja, Timo Alaviuhkola, Kaija Suomi ja Irma Immonen \\ Maatalouden tutkimuskeskus
}

Lihasikojen kasvatuskokeessa selvitettiin porsaskauden rajoitetun ruokinnan vaikutusta lihasikakauden tuotantotuloksiin sekä kantakoeindeksiin. 120 eläimestä muodostettiin kaksi ryhmäă siten, ettă 8 eläintä samasta pahnueesta muodosti kaksi kantakoeryhmäă ( 2 emakkoa ja 2 leikkoa). Seitsemän viikon iästä 25 kilon elopainoon rajoitetun ruokinnan ryhmä sai rehua $30 \%$ văhemmăn kun vertailuryhmä. Lihasikakaudella (25-100 kg) molemmat ryhmät saivat yhtä paljon rehua rajoitetusti elopainon mukaan 1.4-3.2 ry/eläin/pv.

Rajoitetulla ruokinnalla ollut ryhmä kasvoi porsaskaudella merkitsevästi hitaammin $(\mathrm{p}<0.001)$ kuin vertailuryhmå $(344,527 \mathrm{~g} / \mathrm{pv})$, koska sen päivittäinen rehumäärä oli merkitsevästi alhaisempi ( $<<0.001)(0.69,0.99 \mathrm{ry} / \mathrm{kasvu}-\mathrm{kg})$. Myös rajoitetun ryhmän kasvuaika oli keskimäărin 7 päivăă pitempi kuin vertailuryhmän $(\mathrm{p}<0.001)$.

Lihasikakaudella rajoitetulla ruokinnalla ollut ryhmå pystyi kompensoimaan porsaskauden heikompaa kasvua. Sen păivăkasvu oli merkitsevästi parempi $(\mathrm{p}<0.01)$ kuin vertailuryhmän $(955,924 \mathrm{~g} / \mathrm{p})$. Rajoitettu ryhmä käytti myös merkitsevästi vähemmän rehua kasvukauden aikana $(\mathrm{p}<0.05)$ $(189.8,196.0 \mathrm{~kg} / \mathrm{eläin})$ ja sen rehuhyötysuhde oli parempi $(\mathrm{p}<0.05)$ kuin vertailuryhmän $(2.52,2.60 \mathrm{ry} / \mathrm{kasvu}-\mathrm{kg})$.

Teuraslaadussa ei ollut eroja koeryhmien välillä. Lihasikakauden tuloksista laskettiin koeryhmille kantakoeindeksit. Rajoitetun ryhmän kk-indeksi oli 6.3 ja vertailuryhmän 2.7 . Suurin ero ryhmien välille tuli tuotanto-ominaisuuksien (päiväkasvu ja rehuhyötysuhde) indeksiosuudessa, jonka keskiarvo oli 1.9 rajoitetulla ja -2.1 vertailuryhmällä.

Tutkimus osoitti, ettă sika pystyy kompensoimaan rajoitetun ruokinnan aiheuttamaa heikentynyttä kasvua, kun rehumäärä nostetaan eläimen tarvetta vastaavalle tasolle. Tutkimuksen perustella kompensatorista kasvua on myös mahdollista väärinkäyttää kantakokeessa ja parantaa indeksipisteitä. 